\title{
ASSESSMENT OF EFFICIENCY OF RURAL SEWAGE TREATMENT PLANT WITH BIOREACTOR
}

\author{
Agnieszka Cupak, Krzysztof Chmielowski, Piotr Bugajski, Ewa Dacewicz
}

Faculty of Environmental Engineering and Land Surveying, University of Agriculture of Krakow, Al. Mickiewicza 24/28, 30-059 Kraków

\begin{abstract}
Research aims

The aim of the conducted research was to assess efficiency of sewage treatment in rural areas in a sewage treatment plant with a sequencing batch reactor (SBR).

Materials and methods

Assessment of effectiveness of wastewater disposal in a treatment plant was carried out using elements of reliability theory. Research covered a period from March 2014 to December 2015. The content of pollution indicators in treated wastewater was compared with limit values included in the Regulation of the Minister of the Environment of November 18, 2014. Reliability analysis was performed for the following pollution indicators: $\mathrm{BOD}_{5}, \mathrm{COD}_{\mathrm{Cr}}$ and total suspended solids. Reliability coefficient RF was assumed as a basis for reliability calculations. Next, technological treatment efficiency index $\left(\mathrm{P}_{\mathrm{so}}\right)$ was calculated.
\end{abstract}

\section{Results and conclusions}

An analysis of treated wastewater in relation to three tested parameters proved that the treatment plant works properly. Limit values of examined indicators - included in the Regulation (Dz. U. 2014 poz. 1800) - have not been exceeded. Also, all the analysed parameters have shown high percentage of pollutant reduction, ranging between $96 \%$ for $\mathrm{COD}_{\mathrm{Cr}}$ and $99 \%$ for $\mathrm{BOD}_{5}$. Obtained values of reliability indicators for the analysed treatment plant confirm its good condition.

Keywords: sewage, sewage treatment plant, reliability

\section{INTRODUCTION}

Rural areas constitute $93.2 \%$ of Poland's territory and are inhabited by 14.9 million people giving approximately $39 \%$ of the total population (GUS, 2014). Increasing number of inhabitants in countryside and rising standard of sanitary facilities lead to fast of development of rural water supply systems, and thus cause a steady growth in volume of discharged sewage from rural settlements. At the same time, infrastructure development determines attractive- ness of a given area, as well as being an opportunity for improving quality of life (Krakowiak-Bal, 2004; Krzanowski and Wałęga, 2006) Accession of Poland to the European Union, for which environmental protection issues have always been a subject of extensive legal regulations, had a great impact on sewage system.

Due to the nature of sewage discharged from rural areas, there are considerable difficulties in maintaining its proper treatment. Therefore, it is necessary to look for solutions that lead to an effective reduction of pollutant load contained in sewage before it is dis-

凶e-mail:a.cupak@ur.krakow.pl 
charged to a receiver. For this reason, treatment plants characterized by significant resistance to flow variation and pollutant load in discharged sewage, low capital consumption, operational reliability, high purification and simplicity of construction and exploitation are preferred in these areas (Kaczor, 2002; Krzanowski and Wałęga, 2006; Chmielowski and Ślizowski, 2009; 2010; Chmielowski et al., 2015, 2016). It should also be borne in mind that wrong selection of technological solution may be connected with operational problems and possible financial penalties imposed for poor quality of sewage discharged, breaching the required regulations (Oliviera and von Sperling, 2008, Kaczor, 2011; Bugajski, 2014; Al-Zahiri, 2015; Bugajski et al., 2016b; Łagożny et al., 2015; Castellet and Molinos-Senante, 2016; Kaczor et al., 2017). This means that there is a need for assessing the operation of existing treatment systems, both in terms of the effectiveness of pollutants reduction in sewage, as well as technological reliability of the process and statistical control of its quality. Such analysis allows recognising irregularities during exploitation, which can be eliminated in future projects or in existing facilities (Krzanowski and Wałęga, 2006; Bugajski et al., 2015; Arnell, 2016). For this purpose, it is necessary to determine reliability indicators that characterize quantitative properties of reliability of a given system. Selecting indicators is not easy, due to lack of unambiguous rules and guidelines. The basis for indicators selected to assess reliability of sewage facilities is mainly an analysis of the conditions and the process of their operation, while for most of facilities, such as sewage treatment plants, these are specific in terms of both functioning and operating (Kwietniewski et al., 1993).

\section{AIM, SCOPE AND METHODOLOGY OF RESEARCH}

The aim of the research was to assess efficiency of sewage treatment in rural areas in a sewage treatment plant with a sequencing batch reactor (SBR). The studied facility is located in the Małopolskie Voivodeship. Wastewater from residential and public buildings is discharged into treatment plants using sanitary sewers. Planned capacity of the treatment plant is $770 \mathrm{~m}^{3} \cdot \mathrm{d}^{-1}$, while the RLM is 4800 . Sewage treatment plant comprises following devices: rare grating, raw sewage pumping station, step grating, distribution chamber with sand trap, sand dewatering station and SBR reactor. The reactor consists of two technological lines. Each includes pressure chamber and open non-pressure chamber. Pressure chamber is connected to non-pressure chamber through slots on a wall above the bottom. Non-pressure chamber has a ventilation grill. Pressure chamber is equipped with membrane diffusers. Also, both chambers have a pump for removal of excess sediment. Pursuant to the Regulation of the Minister of the Environment on the conditions required for sewage drain-off to waters or ground, and on substances particularly harmful for aquatic environment (Dz. U. 2014 poz. 1800), maximum pollutant concentrations cannot exceed: for total suspension $35 \mathrm{mg} \cdot \mathrm{dm}^{-3}, \mathrm{BOD}_{5} 25 \mathrm{mgO}{ }_{2} \cdot \mathrm{dm}^{-3}$ and $\mathrm{COD}_{\mathrm{Cr}} 125 \mathrm{mgO}_{2} \cdot \mathrm{dm}^{-3}$.

To assess the effectiveness of wastewater disposal in a treatment plant it was necessary to apply elements of reliability theory. Research covered the period from March 2014 to December 2015. The content of pollution indicators in treated wastewater was compared with limit values included in the Regulation of the Minister of the Environment of November 18, 2014 (Dz. U. 2014 poz. 1800), for RLM from 2000 to 9999. Reliability analysis was performed for the following pollution indicators: $\mathrm{BOD}_{5}, \mathrm{COD}_{\mathrm{Cr}}$ and total suspended solids. To this end, basic statistical characteristics such as arithmetic mean, standard deviation, variation coefficient, minimum and maximum value were defined. Reliability factor RF from formula (1) was adopted for reliability calculations (Andraka, 1997)

$$
R F=\frac{\dot{m}_{x}}{X_{a c c}}[-]
$$

given that:

$m_{x}-$ average value of a given indicator in treated wastewater $\left[\mathrm{mg} \cdot \mathrm{dm}^{-3}\right]$,

$X_{a c c}$ - acceptable value of an indicator in treated wastewater $\left[\mathrm{mg} \cdot \mathrm{dm}^{-3}\right]$.

Next, technological purity index was calculated $\left(\mathrm{P}_{\text {so }}\right)$ from the formula (2) (Kwietniewski et al., 1993):

$$
P_{s o}=\frac{n_{z}}{(N+1)}
$$


given that:

$n_{z}-$ number of test results compliant with limit values,

$N$ - number of all test results for a given indicator.

This indicator defines technological reliability of sewage treatment plants and can be used as a simple tool to assess the proper functioning of a facility. It also allows to forecast the reliability of the facility's operation and to estimate risk of non-compliance with formal requirements as to the quality of treated wastewater, in association with an analysis of probability distribution of a random variable (Andraka and Dzienis, 2013).

In the paper, the percentage of reduction of the tested pollutants was also determined (3):

$$
\eta=\frac{S_{r}-S_{t}}{S_{r}} \cdot 100 \%
$$

given that:

$S_{r}$ - content of pollutant index in raw sewage $\left[\mathrm{mg} \cdot \mathrm{dm}^{-3}\right]$,

$S_{t}$ - content of pollutant index in treated wastewater $\left[\mathrm{mg} \cdot \mathrm{dm}^{-3}\right]$.

In addition, an analysis of the amount of sewage flowing into the treatment plant was performed.

\section{RESULTS AND DISCUSSION}

Dynamics of changes in volume of raw and treated wastewater from the analysed sewage treatment plant are presented in Tab. 1.
The data from Table 1 shows that minimum, average and maximum volumes of raw and treated wastewater, in both analysed years, were similar to each other. There is also a significant difference in volume of wastewater flowing into the sewage treatment plant - in the analysed period more sewage flowed in than it drained away. This may indicate accidental waters present in an inflow (almost 60\%). Excess wastewater is discharged into a retention tank. Such a large amount of accidental waters is probably caused by poor technical condition of the sewerage network, which contributes to a significant inflow of rainwater or snowmelt. According to Kaczor (2009), there are two main causes of large inflow of accidental waters - location of manhole sewers beneath the level of a roadway or sidewalk, as well as a possibility of damaging the top of a manhole by heavy vehicles and local street and pavement repairs. Thus, a dip is created, where rainwater or snowmelt gather, which then penetrate inside a manhole through ventilation openings or slots used to lift the manhole cover. An increased amount of sewage inflow with foreign water has a negative impact on the functioning of sewage treatment plants in both economic and technological terms - it can lead to excessive dilution of sewage during rainy weather and reduce pollution disposal efficiency (Bugajski et al., 2016a).

In the case of the analysed sewage treatment plant, an efficiency of wastewater treatment was measured for three pollution indicators: $\mathrm{BOD}_{5}, \mathrm{COD}_{\mathrm{Cr}}$ and total suspended solids. Basic statistical characteristics of analysed pollution indicators included raw and treated wastewater, in the 2014-2015 research years, are presented in Table 2.

Table 1. Quantitative characteristics of raw and treated wastewater outflowing from analysed plant in years 2014-2015

\begin{tabular}{|c|c|c|c|c|c|}
\hline \multirow{3}{*}{ Characteristics } & \multirow{3}{*}{ Unit } & \multicolumn{4}{|c|}{ Year } \\
\hline & & \multicolumn{2}{|c|}{2014} & \multicolumn{2}{|c|}{2015} \\
\hline & & raw wastewater & treated wastewater & raw wastewater & treated wastewater \\
\hline Mean daily outflow & $\mathrm{m}^{3} \cdot \mathrm{d}^{-1}$ & 655.3 & 260.2 & 655.7 & 275.8 \\
\hline Maximum daily outflow & $\mathrm{m}^{3} \cdot \mathrm{d}^{-1}$ & 910 & 313 & 840 & 320 \\
\hline Minimum daily outflow & $\mathrm{m}^{3} \cdot \mathrm{d}^{-1}$ & 490 & 230 & 500.5 & 239 \\
\hline Standard deviation & $\mathrm{m}^{3} \cdot \mathrm{d}^{-1}$ & 151.8 & 24.7 & 114.4 & 28.5 \\
\hline Total annual outflow & $\mathrm{m}^{3} \cdot 10^{3}$ & 7.9 & 3.12 & 7.9 & 3.31 \\
\hline
\end{tabular}


Cupak, A., Chmielowski, K., Bugajski, P., Dacewicz, E. (2019). Assessment of efficiency of rural sewage treatment plant with bioreactor. Acta Sci. Pol., Formatio Circumiectus, 18(1), 137-143 DOI: http://dx.doi.org/10.15576/ASP.FC/2019.18.1.137

Table 2. Basic statistical characteristics of analysed pollutants in raw and treated wastewater in years 2014-2015

\begin{tabular}{lcccccc}
\hline \multirow{2}{*}{ Parameter } & Wastewater & \multicolumn{5}{c}{ Statistics } \\
\cline { 2 - 7 } & & $\begin{array}{c}\text { Mean } \\
{\left[\mathrm{mg} \cdot \mathrm{dm}^{-3}\right]}\end{array}$ & $\begin{array}{c}\text { Maximum } \\
{\left[\mathrm{mg} \cdot \mathrm{dm}^{-3}\right]}\end{array}$ & $\begin{array}{c}\text { Minimum } \\
{\left[\mathrm{mg} \cdot \mathrm{dm}^{-3}\right]}\end{array}$ & $\begin{array}{c}\text { Stand. dev. } \\
{\left[\mathrm{mg} \cdot \mathrm{dm}^{-3}\right]}\end{array}$ & $\begin{array}{c}\text { Variation coefficient } \\
{[-]}\end{array}$ \\
\hline \multirow{2}{*}{$\mathrm{BOD}_{5}$} & raw & 307.4 & 573.0 & 133.0 & 137.6 & 0.45 \\
\hline \multirow{2}{*}{$\mathrm{COD}_{\mathrm{Cr}}$} & treated & 3.4 & 7.9 & 0.9 & 2.2 & 0.66 \\
\hline \multirow{2}{*}{ Total suspension } & raw & 831.4 & 1510.0 & 155.0 & 474.2 & 0.57 \\
\cline { 2 - 7 } & treated & 29.5 & 44.0 & 19.0 & 9.6 & 0.33 \\
\hline
\end{tabular}

Raw sewage (see: Table 2) flowing into the analysed sewage treatment plant was defined by concentration of organic pollutants typical for domestic wastewater and did not differ from composition confirmed by other authors (Krzanowski and Wałęga, 2004, Chmielowski, 2008, Chmielowski and Ślizowski, 2008, 2010). BOD $_{5}$ content in raw sewage ranged from 133.0 to $573.0 \mathrm{mg} \mathrm{O} \cdot \mathrm{dm}^{-3}$. Whereas variation coefficient was 0.45 , indicating wide dispersion. The next parameter $-\mathrm{COD}_{\mathrm{Cr}}-$ ranged from 155.0 to $1510.0 \mathrm{mg} \mathrm{O}_{2} \cdot \mathrm{dm}^{-3}$, with an average value of $831.4 \mathrm{mg} \mathrm{O}_{2} \cdot \mathrm{dm}^{-3}$. In this case, similarly as for $\mathrm{BOD}_{5}$, it was characterized by high variability (variation coefficient amounted to 0.57). As to total suspended solids, a very high variability of the parameter is observed in raw sewage, as demonstrated by a high variation coefficient of almost 0.71 . The range of indicator in raw sewage amounted to $1021.0 \mathrm{mg} \cdot \mathrm{dm}^{-3}$ (average value was $500.8 \mathrm{mg} \cdot \mathrm{dm}^{-3}$ ).

For treated wastewater the average content of $\mathrm{BOD}_{5}$ was $3.4 \mathrm{mg} \mathrm{O} \mathrm{O}_{2} \cdot \mathrm{dm}^{-3}$ (value range $7 \mathrm{mg} \mathrm{O}_{2} \cdot \mathrm{dm}^{-3}$ ). The acceptable value of the indicator included in the Regulation (Dz. U. 2014 poz. 1800), amounting to $25 \mathrm{mg} \mathrm{O} \cdot \mathrm{dm}^{-3}$, was not breach at any moment of measurement. The average percentage of reduction of $\mathrm{BOD}_{5}$ content for both analysed years was similar and amounted to almost $99 \%$ (see: Fig. 1).

In turn, the content of $\mathrm{COD}_{\mathrm{Cr}}$ in treated wastewater in the examined period ranged from 19 to $44 \mathrm{mg} \mathrm{O} \cdot \mathrm{dm}^{-3}$ (see: Table 2), with an average value of $29.5 \mathrm{mg} \mathrm{O}{ }_{2} \cdot \mathrm{dm}^{-3}$. As it was for $\mathrm{BOD}_{5}$, the content of $\mathrm{COD}_{\mathrm{Cr}}$ in the studied period did not exceed limit value $\left(125 \mathrm{mg} \mathrm{O}_{2} \cdot \mathrm{dm}^{-3}\right)$. The average rate of indicator reduction was high, approximately $96 \%$ (see: Fig. 1).

For total suspended solids an average concentration of the indicator in treated wastewater oscillated between $1.9 \mathrm{mg} \cdot \mathrm{dm}^{-3}$ and $20 \mathrm{mg} \cdot \mathrm{dm}^{-3}$, with an average value of almost $7 \mathrm{mg} \cdot \mathrm{dm}^{-3}$. Similarly to raw sewage, treated wastewater demonstrated a wide variation of the indicator, as evidenced by variation coefficient of 0.71 . Permissible concentration of the indicator (35 $\mathrm{mg} \mathrm{O}_{2} \cdot \mathrm{dm}^{-3}$ ) was not exceeded throughout the research period. An average percentage of reduction for total suspension was $98 \%$.

On the basis of an analysis of treated wastewater, in reference to three parameters $-\mathrm{BOD}_{5}, \mathrm{COD}_{\mathrm{Cr}}$ and total suspended solids - it was concluded that the studied treatment plant works properly. Limit values of the examined indicators - included in the Regulation (Dz. U. 2014 poz. 1800) - have not been exceeded.

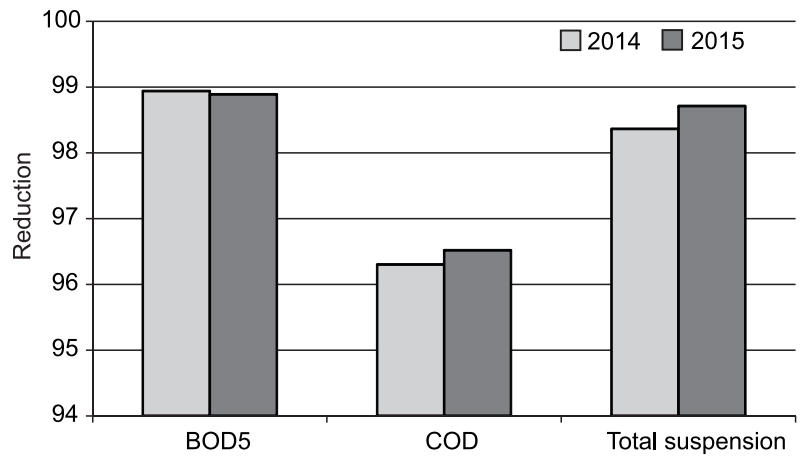

Fig. 1. Reduction of analysed pollution indicators in years 2014 and 2015 
Also, all the analysed parameters have shown high percentage of pollutant reduction, ranging between $96 \%$ for $\mathrm{COD}_{\mathrm{Cr}}$ and $99 \%$ for $\mathrm{BOD}_{5}$.

Table 3 presents the results of calculations of reliability indicators for the analysed sewage treatment plant. Obtained values of reliability indicators for the analysed treatment plant confirm its good condition.

Table 3. Indicators of reliability for analysed wastewater treatment plant

\begin{tabular}{cccc}
\hline \multirow{2}{*}{ Parameter } & \multicolumn{3}{c}{ Indicator } \\
\cline { 2 - 4 } & $\mathrm{RF}$ & $\mathrm{P}_{\text {so }}$ & $\square$ \\
\hline $\mathrm{BOD}_{5}$ & 0.13 & 0.93 & 0.98 \\
\hline $\mathrm{COD}_{\mathrm{Cr}}$ & 0.24 & 0.93 & 0.96 \\
\hline Total suspension & 0.19 & 0.93 & 0.98 \\
\hline
\end{tabular}

Values of calculated reliability indicators, summarized in Table 3, prove its good condition. The reliability coefficient RF delivered low values for each analysed indicator (from 0.13 for $\mathrm{BOD}_{5}$ to 0.24 for $\mathrm{COD}_{\mathrm{Cr}}$ ), which proves that the treatment plant operates properly. In turn, for technological efficiency indicator $\left(\mathrm{P}_{\mathrm{so}}\right)$, for each analysed indicator, values equal to 0.93 were recorded, which proves its proper functioning. The obtained results of reliability coefficient $\mathrm{RF}, \mathrm{P}_{\mathrm{so}}$ and for $\mathrm{BOD}_{5}, \mathrm{COD}_{\mathrm{Cr}}$ and the total suspended solids are similar to those obtained by Młyński et al. (2016) for the sewage treatment plant in Jasło. $P_{\mathrm{so}}$ has shown slightly higher values -1.0 (for $\mathrm{COD}_{\mathrm{Cr}}$ and total suspended solids) and $0.99\left(\mathrm{BOD}_{5}\right)$. Wąsik and Chmielowski (2013) obtained similar values of $\mathrm{P}_{\mathrm{so}}$ indicator (0.96) for the sewage treatment plant in Skala-Nowa Wieś. Młyński et al. (2016) indicate that $\mathrm{RF}$ indicator values for $\mathrm{BOD}_{5}$ and $\mathrm{COD}_{\mathrm{Cr}}$ were slightly higher than presented in this paper $(0.24$ and 0.28 , respectively). For total suspended solids the RF value obtained in this study was slightly higher than that presented by Młyński et al. (2016) (i.e. at the level of 0.13).

\section{CONCLUSIONS}

The performed tests on effectiveness of wastewater treatment in rural areas in a sewage treatment plant with a SBR reactor provide with following conclusions:
1. Raw sewage flowing into the analysed treatment plant, in terms of the examined pollutant indicators, was similar to typical domestic sewage.

2. Average reduction of pollutants in sewage treatment plants in 2014 and 2015 was very high, about $99 \%$ for $\mathrm{BOD}_{5}$, about $96 \%$ for $\mathrm{COD}_{\mathrm{Cr}}$, and $98 \%$ for total suspended solids.

3 . In the studied period, in all tested samples of treated wastewater, the content of organic compounds $\left(\mathrm{BOD}_{5}, \mathrm{COD}_{\mathrm{Cr}}\right)$ and total suspended solids were below the limits specified in the Regulation of the Minister of the Environment of November $18,2014$.

4. The calculated values of reliability indicators for the tested treatment plant confirm its high efficiency.

\section{REFERENCES}

Andraka, D. (1997). Prognozowanie niezawodności oczyszczalni ścieków na przykładzie miej-skiej oczyszczalni w Grajewie. Mat. IX Ogólnopolskiej Konferencji Naukowo-Technicznej z cyklu „Problemy gospodarki wodno-ściekowej w regionach rolniczo-przemysłowych", Rajgród 16-24 czerwca 1997, 366-373.

Andraka, D., Dzienis, L. (2013). Modelowanie ryzyka w eksploatacji oczyszczalni ścieków. Rocznik Ochrony Środowiska, 15, 1111-1125.

Al-Zahiri, A. (2015). Assessment of Performance of Wastewater Treatment Plants in Jordan. International Journal of Civil and Environmental Engineering, 1-6.

Arnell, M. (2016). Performance Assessment of Wastewater Treatment Plants. Multi-Objective Analysis Using Plant-Wide Models. Ph.D. Thesis, Lund University, Lund, Sweden.

Bugajski, P. (2014). Analiza niezawodności funkcjonowania oczyszczalni Bioblok PS-50 z zastosowaniem metody Weibulla. Infrastruktura i Ekologia Terenów Wiejskich, 2, 667-677.

Bugajski, P., Chmielowski, K., Kaczor, G. (2016a). Wpływ wielkości dopływu wód opadowych na skład ścieków surowych w małym systemie kanalizacyjnym. Acta Sci. Pol. Formatio Circumiectus, 15 (2), 1-9.

Bugajski, P., Chmielowski, K., Kaczor, G. (2016b). Reliability of a Collective Wastewater Treatment Plant, Journal of Ecological Engineering, 17, 4, 143-147, DOI:10.12911/22998993/64505

Bugajski, P., Kaczor, G., Bergel, T. (2015). Niezawodność usuwania azotu ze ścieków w zbiorczej oczyszczalni z se- 
kwencyjnym reaktorem biologicznym. Acta Scientiarum Polonorum, Formatio Circumiectus, 14 (3), 19-27.

Castellet, L., Molinos-Senante, M. (2016). Efficiency assessment of wastewater treatment plants: A data envelopment analysis approach integrating technical, economic, and environmental issues. Journal of Environmental Management, 167, 160-166.

Chmielowski, K. (2008). Eliminacja zanieczyszczeń ze ścieków komunalnych w oczyszczalni w Dąbrowie Tarnowskiej. Infrastruktura i Ekologia Terenów Wiejskich, 5, 149-158.

Chmielowski, K., Bugajski, P., Wąsik, E. (2015). Ocena działania oczyszczalni ścieków w Haczowie przed i po modernizacji. Infrastruktura i Ekologia Terenów Wiejskich, 4, 949-964.

Chmielowski, K., Bugajski, P., Kaczor, G. (2016). Compositional analysis of the sewage incoming to and discharged from the sewage treatment plant in Kolbuszowa Dolna, in: Journal of Ecological Engineering, 17, 5, 9-16, DOI: 10.12911/22998993/64446

Chmielowski, K., Ślizowski, R. (2009). Ocena skuteczności usuwania zanieczyszczeń w oczyszczalni ścieków w Tarnowie. Infrastruktura i Ekologia Terenów Wiejskich, 5, 137-146.

Chmielowski, K., Ślizowski, R. (2010). Ocena skuteczności oczyszczania ścieków w oczyszczalni ścieków w Nowym Sączu - Wielopolu. Infrastruktura i Ekologia Terenów Wiejskich, 2, 155-167.

GUS, Ochrona Środowiska (2014). Warszawa.

Kaczor, G. (2011). Wpływ wiosennych roztopów śniegu na dopływ wód przypadkowych do oczyszczalni ścieków bytowych. Acta Sci. Pol., Formatio Circumiectus, 10 (2), 27-34.

Kaczor, G., (2009). Otwory we włazach kanalizacyjnych jako jedna z przyczyn przedostawania się wód przypadkowych do kanalizacji sanitarnej. Infrastr. Ekol. Ter. Wiej. 9, 155-163.

Kaczor, G. (2002). Prognozowanie dobowych dopływów ścieków do oczyszczalni wiejskich na podstawie wybranych miejscowości. Acta Sci. Pol., Formatio Circumiectus, 1(1), 7-20.
Kaczor, G., Chmielowski, K., Bugajski, P. 2017. Wpływ sumy rocznej opadów atmosferycznych na objętość wód przypadkowych dopływających do kanalizacji sanitarnej. Rocznik Ochrona Środowiska, 19, 668-681.

Krakowiak-Bal, A. (2004). Infrastruktura techniczna wiejskich gmin górskich w aspekcie ich wielofunkcyjnego rozwoju. Infrastruktura i Ekologia Terenów Wiejskich, 3.

Krzanowski, S., Wałęga, A. (2006). Wykorzystanie teorii niezawodności i statystycznej kontroli jakości do oceny eksploatacyjnej wiejskich oczyszczalnie ścieków. Infrastruktura i Ekologia Terenów Wiejskich, 3/2, Polska Akademia Nauk, Oddział w Krakowie, 17-37.

Krzanowski, S., Wałęga, A. (2004). Ocena niezawodności działania mechaniczno-biologicznej oczyszczalni ścieków dla miasta Dąbrowa Tarnowska. Zesz. Nauk. ATH, Seria Inżynieria Włókiennicza i Ochrona Środowiska, 14(5), 97-104.

Kwietniewski, M., Roman, M., Kłoss-Trębaczkiewicz, H. (1993). Niezawodność wodociagów i kanalizacji. Arkady.

Łagożny, P., Maj, K., Masłoń, A. (2015). Technological efficiency of the wastewater treatment plant in Krosno. Archiwum Gospodarki Odpadami i Ochrony Środowiska, 2, 113-122.

Młyński, D., Chmielowski, K., Młyńska, A., Miernik, W. (2016). Ocena skuteczności pracy oczyszczalni ścieków w Jaśle. Infrastruktura i Ekologia Terenów Wiejskich Nr 1/1, Polska Akademia Nauk, Oddział w Krakowie, 147-162.

Oliviera, S.C., von Sperling, M. (2008). Reliability analysis of wastewater treatment plant. Water Research. 42, 1182-1194.

Rozporządzenie Ministra Środowiska z dnia 18 listopada 2014 r. w sprawie warunków, jakie należy spełnić przy wprowadzaniu ścieków do wód lub do ziemi, oraz w sprawie substancji szczególnie szkodliwych dla środowiska wodnego (Dz. U. 2014 poz. 1800).

Wąsik, E., Chmielowski, K. (2013). Ocena funkcjonowania oczyszczalni ścieków Skała-Nowa Wieś, Gaz, Woda i Technika Sanitarna, 8, 328-330. 


\section{OCENA SKUTECZNOŚCI PRACY WIEJSKIEJ OCZYSZCZALNI ŚCIEKÓW Z REAKTOREM BIOLOGICZNYM}

\section{ABSTRAKT}

\section{Cel pracy}

Celem przeprowadzonych badań była ocena skuteczności oczyszczania ścieków wiejskich w oczyszczalni $\mathrm{z}$ reaktorem o działaniu sekwencyjnym (SBR).

\section{Materiat i metody}

Ocenę efektywności usuwania zanieczyszczeń w oczyszczalni określono przy wykorzystaniu elementów teorii niezawodności. Badania obejmowały okres od marca 2014 do grudnia 2015 roku. Zawartości wskaźników zanieczyszczeń w ściekach oczyszczonych porównano z wartościami granicznymi zawartymi w Rozporządzeniu Ministra Środowiska z dnia 18 listopada 2014 roku . Analiza niezawodności została przeprowadzona dla następujących wskaźników zanieczyszczeń: BZT5, ChZTCr i zawiesiny ogólnej. Jako podstawę do obliczeń niezawodnościowych przyjęto współczynnik niezawodności WN Następnie obliczono wskaźnik technologicznej sprawności oczyszczania (Pso).

\section{Wyniki i wnioski}

Na podstawie analizy ścieków oczyszczonych, w odniesieniu do badanych trzech parametrów stwierdzono, że analizowana oczyszczalnia pracuje prawidłowo. Zawarte w Rozporządzeniu (Dz. U. 2014 poz. 1800) graniczne wartości badanych wskaźników nie zostały przekroczone. Również w przypadku wszystkich badanych parametrów obserwowano wysoki procent redukcji zanieczyszczeń, który wyniósł od 96\% w przypadku ChZTCr, do 99\% dla BZT5. Uzyskane wartości wskaźników niezawodności analizowanej oczyszczalni potwierdzają jej bardzo dobre funkcjonowanie.

Słowa kluczowe: ścieki, oczyszczalnia ścieków, niezawodność 